\title{
The Importance of TOAFL in Improving the Language Skills of Arabic Language Education of Sixth Semester Students at Universitas Muhammadiyah Yogyakarta
}

\author{
Mohamad Muhajiri,"* Mohamad Naim Madjid ${ }^{2}$
}

\author{
${ }^{1}$ Arabic language education, Faculty of language education, Muhammadiyah University of Yogyakarta, Yogyakarta, Indonesia \\ ${ }^{2}$ Arabic language education, Faculty of language education, Muhammadiyah University of Yogyakarta, Yogyakarta, Indonesia \\ *Email: hajirmesir@umy.ac.id
}

\begin{abstract}
The research discusses the urgency of TOAFL (Test of Arabic as a Foreign Languagen) in Improving the linguistic skills of sixth-semester student of the Arabic Language Education Study Program, Universitas Muhammadiyah Yogyakarta. There were 15 students as samples chosen using the simple random sampling method selecting random samples provides equal opportunity and position for the entire population. The study used a qualitative method with a discriptive analysis approach to describe data obtained from the TOAFL test. The data collection method was bases on several stages, including obsevation, interviews, and documentation. The most imporant results in the TOAFL exam include three language skills; listening, reading, and writing. Students who were sampled had gives significant improvement in their language abilities. It was addressed by the scores abtained on thwo exams on each language abilty, with the details; 15 students got impreved grades in their listening abilities, and only 1 student got the same score on the secend exam. There were 9 students whose grades imprived from the first test to the second exam, and 6 students decreased in reading skills. In writing, there were 10 students whose grades improved form the frirst exam tho the second, and three students are the same or unchanged grades, and the other decreased. A significant high average value was obtained in listening with an average level of $45 \%$.
\end{abstract}

Keywords: Urgency, TOAFL Test, Arabic Ability

\section{INTRODUCTION}

A language is a communication tool in the form of a system of sound symbols produced by human speech. It consists of one word or word arrangement connected abstractly between the word as a symbol and the object or concept represented, the word order or vocabulary. The speaker must arrange words alphabetically or according to alphabetical order to understand a language. Language is also a means of self-expression as well as a tool to show one's identity.

Language is the primary weapon in communicating so that what is conveyed by someone can be understood by the interlocutor. Therefore, it is not surprising that many people learn various languages. As an Indonesian citizen, the majority of whose population is Muslim, here Arabic should also be mastered since Al-Qur'an, the source of Muslims' teachings, is written in Arabic.
In the world of education other than English, Arabic is also necessary to learn [1].

Learning Arabic or a foreign language is different from learning the mother tongue. Therefore, learning must be different, starting from the method and process of implementing the learning. Arabic has four skills, which include listening skills (maharah al-Istima'), speaking skills (maharah al-kalam), reading skills (maharah al-qira'ah), and writing skills (mahaarah al Kitaabah).

The main point for Muslims studying Arabic is to understand the Al-Quran and Al-Hadith, as a guide. Besides, Arabic is also the primary medium to explore previous science in medicine (ancient scientific theories), social, political, economics, and other Arabic sciences. For this reason, it is not surprising that Muslims in Indonesia pay great attention to Arabic. 
Arabic is the language of Muslims and the second language of communication after English.

A person's Arabic proficiency can be measured through a language proficiency test, known as the TOAFL (Test of Arabic as a Foreign Language). In this test, the material is comprehensive and requires understanding and mastery of a lot of vocabulary. The answers and the results of the assessment are objective and definite [2].

Besides improving TOAFL language skills, it can also improve the quality of Arabic Language Education in an educational institution. However, TOAFL should have been used by final year students for graduation requirements in Arabic Language Education at Universitas Muhammadiyah Yogyakarta (UMY). Unfortunately, there has not been any further plan.

Indeed, the Arabic Language Education Study Program of UMY should have TOAFL. The study program's graduates will undoubtedly continue their studies in the Middle East or become a graduation requirement as proof of proficiency and additional document for applying for jobs in the Arabic language field.

Many universities, both national and international, require the TOAFL for registration, especially study programs that use Arabic as the instruction language. With this problem, the researcher would like to apply the TOAFL test to improve Arabic language skills. Hopefully, in the future, students who graduate from the Arabic Language Education Study Program, UMY continue their education outside Indonesia. They can improve their ability in Arabic at a higher level.

\section{METHODOLOGY}

This research approach is qualitative research and quantitative. The researcher used a descriptive analysis approach method with the correlation method, explaining how much influence and importance the TOAFL exam had in increasing learning proficiency in the Arabic Language Education Study Program at UMY. Qualitative research requires a lot of preparation and planning. Researchers must use observational techniques and interview strategies and collect data to solve research problems in this context.

The population and research sample were students of the 6th semester of the Arabic Language Education study program in the academic year 2019/2020, with four skills. Researchers can handle data and find something meaningful in what may seem a complete mess and verify separate individual fact data leading to the same results.

The researcher took the information as a source of data, which included respondents and informants. In this case, the informant used to get the observation information results was the head of the Department of Language Education, the head of administration of Language Education, and sixth-semester students in the Arabic Language Education Study Program at UMY the academic year 2019/2020.

A research location is a place related to the purpose. This research took place at Universitas Muhammadiyah Yogyakarta. Data or document literature is written material or objects related to a particular event or activity, and it can be a recording or a written document. In this study, the researcher used a document in the form of a photo to reinforce observations and research. The other documents were from books, journals, and theses.

The data collection techniques and instruments used in this study were first-Observation. It is a technique or method of collecting data by observing ongoing activities [3]. The observation method used by the researcher was the non-participatory observation method. The researcher did not participate in activities and only observed the activity. In the observation, the researcher used an observation guide with geographic and environmental conditions, the implementation of language learning Arabic, the state of the infrastructure, and teachers' and students' conditions.

Second, an interview is one technique for collecting and recording data, information, or opinions through conversations and questions and answers, both directly and indirectly, with data sources. Interviews aim at lecturers and students to obtain information about the implementation of activities at school. An interview is a set of questions asked verbally to people who can provide information or explanation. In this case, the interview was conducted to determine the factors that affect the muhadatsah ability and TOAF score.

Third, documentation is a research method that looks for data on variables in the form of notes, transcripts, books, newspapers, magazines, inscriptions, meeting minutes, leggers, agendas, etc. The documentation method collects data through written objects such as books, magazines, documents, regulations, meeting minutes, and daily notes. This 
method was to obtain data regarding the history and profile of study programs, organizational structure, vision and mission of study programs, employees, conditions of facilities and infrastructure, and matters related to the effectiveness of Arabic learning activities. Several data collection instruments were required, such as observation sheets, recording equipment, digital/cellphone cameras, interview guides, observation guidelines, questionnaire sheets, and stationery.

Fourth is the TOAFL test practice. This training would obtain data on the level at which the improvement of Arabic learning after applying the TOAFL test. In this training, the researcher used online media with the TOAFL.com page. This exercise lasted for two days. The first day was for introductions, then the first practice. The second day was the TOAFL for non-native speakers. Within two days, the results would be obtained from the first and second training scores, and the test takers could gain a better score in the second exercise.

This research took a sample of 15 sixth-semester, the Arabic Language Education Study Program, UMY academic year 2019/2020, from class A. The sample selection is based on a simple random sampling method. It is a sampling technique in which each component of the population has an equal chance of being selected in the sample.

The choice of elements depends entirely on chance or probability, so this sampling technique is sometimes known as the odds method. Simple random sampling is a fair sampling technique [4]. This study was limited to fourteen to twenty students who became the sample.

\section{RESULT AND DISCUSSION}

TOAFL.com website is a computer-based Arabic language proficiency test developed by Eckehard Schulz, Professor at the Oriental Institute University of Leipzig. The exercises in TOAFL.com include three skills (listening, reading, and writing). Each skill included 25 points, which would test the students' ability to master Arabic. Later, it would show the results of indicators whether students in the study program needed a TOAFL exam to support the improvement of Arabic learning.

Researcher also interviewed 15 students in which they hoped that UMY would hold TOAFL exercises. They have been aware of the importance of TOAFL to improve language competence. On the other hand, many students have never taken TOAFL or know that it can be a requirement before graduating.

TOAFL is a tool because tests have an essential role in education. A good test is based on the quality of good education and study. The Arabic language competency test can present an Arabic language education program's language proficiency so students can find out the level of ability and absorption of language teaching materials. This test consists of questions for listening and reading. The questions from each component have been provided in the TOAFL test. There is no test similar to TOEFL in the Arabic language as an international standard [5].

The following are the interview (3/2/20, 6:25 PM0 results of 15 respondents.

Table 1. Interview Result

\begin{tabular}{|l|l|c|}
\hline No & \multicolumn{1}{|c|}{$\begin{array}{c}\text { In your opinion, is TOAFL } \\
\text { important? }\end{array}$} & Respondent \\
\hline 1 & $\begin{array}{l}\text { Yes, as it can measure one's } \\
\text { Arabic language ability. }\end{array}$ & \\
\hline 2 & Yes, very important & \\
\hline 3 & Important & \\
\hline 4 & Very important & $2 \mathrm{x}$ \\
\hline 5 & Yes, important & $5 \mathrm{x}$ \\
\hline 6 & Important & $3 \mathrm{x}$ \\
\hline 7 & Yes & \\
\hline 8 & Yes & \\
\hline
\end{tabular}

Table 2. Interview Result

\begin{tabular}{|l|l|}
\hline No & $\begin{array}{c}\text { Do you agree if the Arabic Language Study } \\
\text { Program of UMY holds TOAFL? }\end{array}$ \\
\hline 1 & Strongly agree \\
\hline 2 & Good, it can train the students to speak Arabic \\
\hline 3 & It is necessary to measure the students' ability \\
\hline 4 & Agree, because it can improve students' ability \\
\hline 5 & Yes, it can train the students to speak Arabic \\
\hline 6 & Strongly agree to help the students \\
\hline 7 & Agree \\
\hline
\end{tabular}

\subsection{Supporting and Inhibiting Factors for the}

\section{Use of TOAFL}

A change in education must always be in line with the era. The world of education is always influenced by several factors that act as supporters and obstacles to change in education. 
These factors can come from within the learning media itself (external factors) and educational developers (internal factors). TOAFL.com needs supportive facilities such as in-class infrastructure (clear sound) and adequate language laboratories, and good internet coverage.

\subsection{The Effectiveness of TOAFL}

In the table below, the data on the TOAFL test's effectiveness will be presented in increasing the Arabic competence of sixth-semester students of the Arabic Language Education Study Program at UMY. The researcher tested 15 students. The percentage increase can be seen at the value obtained. The researcher used the percentage reduction formula, calculated by the formula $\min$ (TOAFL 2 - TOAFL 1 = percentage increase in value). Then, the researcher also looked for the average percentage value obtained through the two stages of the TOAFL exam, namely using the Average formula [6].

$x=\sum_{i=1} x 1 n$

Table 3. Overall TOAFL Exam Results

\begin{tabular}{|l|l|l|l|l|l|}
\hline \multirow{2}{*}{ No. } & \multirow{3}{*}{$\begin{array}{l}\text { Students } \\
\text { Names }\end{array}$} & \multicolumn{4}{|c|}{ Value of Percentage Increase } \\
\cline { 3 - 6 } & & Listening & Reading & Writing & TOAFL \\
\hline 1 & SM & $60 \%$ & $20 \%$ & $-2 \%$ & $34.73 \%$ \\
\hline 2 & AS & $33 \%$ & $-9 \%$ & $0 \%$ & $12.54 \%$ \\
\hline 3 & DKN & $53 \%$ & $-5 \%$ & $0 \%$ & $24.27 \%$ \\
\hline 4 & NI & $45 \%$ & $1 \%$ & $10 \%$ & $22.03 \%$ \\
\hline 5 & RM & $23 \%$ & $5 \%$ & $10 \%$ & $9.98 \%$ \\
\hline 6 & HHP & $40 \%$ & $39 \%$ & $30 \%$ & $55.42 \%$ \\
\hline 7 & SP & $20 \%$ & $-9 \%$ & $0 \%$ & $8.45 \%$ \\
\hline 8 & HM & $48 \%$ & $47 \%$ & $0 \%$ & $52.81 \%$ \\
\hline 9 & QAF & $33 \%$ & $-9 \%$ & $12 \%$ & $12.54 \%$ \\
\hline 10 & RKR & $0 \%$ & $-13 \%$ & $40 \%$ & $2.04 \%$ \\
\hline 11 & ZNR & $58 \%$ & $-20 \%$ & $20 \%$ & $17.23 \%$ \\
\hline 12 & MH & $60 \%$ & $43 \%$ & $49 \%$ & $70.54 \%$ \\
\hline 13 & AZF & $68 \%$ & $15 \%$ & $29 \%$ & $41.72 \%$ \\
\hline 14 & TN & $45 \%$ & $11 \%$ & $18 \%$ & $30.02 \%$ \\
\hline 15 & ANF & $90 \%$ & $27 \%$ & $29 \%$ & $54.70 \%$ \\
\hline Average Increase & $45 \%$ & $10 \%$ & $16 \%$ & $30 \%$ \\
\hline Percentage & & & & \\
\hline
\end{tabular}

From the table above, it can be concluded that:

1. no students are experiencing a decrease in the percentage value of listening proficiency and with an average increase of $45 \%$
2. 9 students experience an increase, and six students experience a decrease in reading proficiency percentage, and the average increase is $10 \%$

3. 14 students get an increase, and only one student experience a decrease in writing proficiency percentage. The average gain is $16 \%$

4. In the overall TOAFL results, all students got a percentage value that increases with an average acquisition rate of $30 \%$.

\section{CONCLUSION}

TOAFL is indeed essential in helping improve Arabic language learning. Students of Arabic Language Study Program, because in this TOAFL, there are beneficial exercises to practice language skills and competencies, such as reading skills, listening skills, and writing skills.

Many students have never taken the TOAFL test even though they are students majoring in Arabic. This issue must receive serious attention, especially in the Arabic Language Education Study Program, Universitas Muhammadiyah Yogyakarta, because TOAFL is also one of the requirements for graduation in the Arabic Language Education Study Program, Muhammadiyah University of Yogyakarta.

Students look forward to holding TOAFL training in the Arabic Language Education Study Program, Muhammadiyah University of Yogyakarta, and expect these facilities to support TOAFL in the future. Using the TOAFL.com program, it is expected to have a strong internet connection and a supportive sound quality because this test requires suitable devices and the internet.

Hopefully, this study program can consider the TOAFL program training facility's existence because students need TOAFL as a medium for increasing Arabic competence. After all, TOAFL also includes Arabic proficiency, such as listening, reading, and writing skills. Being a student who can be fluent in Arabic is always to hone it and practice it, apart from reading books and getting used to speaking Arabic is by doing cognitive sharpening through a series of TOAFL tests. 


\section{REFERENCES}

[1] Aflisia, Noza, The relationship between muhadatsah abilities and TOAFL scores: Journal of An Nabighoh Volume 19 No. 02 (2017).

[2] Slide Presentation of TOAFL Learning at MAN 4 Jakarta in 2010 by Dr. Muhbib Abdul Wahab, M.Ag (Lecturer in Arabic Language at UIN Syarif Hidayatullah Jakarta)

[3] Hassoun Jaafar Al-Qaim. Faculty of arts. Media department. Stage 3. University of Babylon.
[4] Sugiyono. Quantitative Research Methods, Qualitative and R \& D. Bandung: Alfabeta Publisher, 2008. Pg. 61

[5] Rini. Mendesain tes Bahasa Arabuntuk Penutur Asing. Ihya Al-Arabiyah: Jurnal Pendidikan Bahasa dan Sastra Arab Volume 5 No. 1 (Januari-Juni) 2019. Institut Agama Islam Negeri Curup.

[6] https://www.rumusstatistik.com/2013/07/rata-ratamean-atau-rataan.html accessed on 04 March 2020. 6:13 $\mathrm{pm}$ 